\title{
MACROECONOMIC DETERMINANTS OF THE CURRENCY AND STOCK MARKET SHOCKS: A PANEL VAR APPROACH
}

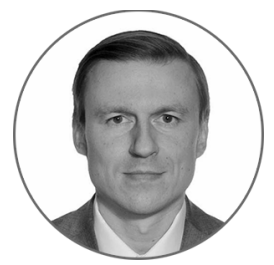

Article history: Received 1 March 2017 Received in revised form 16 March 2017

Accepted 31 March 2017

Translated 2 October 2017

Available online 14 December 2017

JEL classification: $\mathrm{E} 44, \mathrm{~F} 31, \mathrm{~F} 45, \mathrm{G} 14$

Keywords: currency shock, Panel Vector Autoregression, VAR, monetary policy

\author{
Aleksandr A. BOROCHKIN \\ National Research Lobachevsky State University of Nizhny Novgorod, \\ Nizhny Novgorod, Russian Federation \\ borochkin@yandex.ru
}

\begin{abstract}
Importance The article addresses the currency and stock market volatility caused by market participants' perception of macroeconomic news that central banks across opened economy countries take into account when making decisions on changes in the monetary policy.

Objectives The study aims to offer a quantitative approach to assessing a reaction of the currency and stock market to macroeconomic news publication.

Methods The study employs descriptive statistics methods. Basic calculations rest on the Panel Vector Autoregression method.

Results News about changes in interest rates, inflation and industrial production instantly trigger financial market volatility in all analyzed countries. I found volatility spillovers from currency to stock markets and vice versa. The aftermaths of the news-related shocks are absorbed by the market during 3-4 days.

Conclusions and Relevance The modern monetary policy of central banks implies no immediate measures against inflation spikes, therefore, the reaction of markets to publication of price indices is quite slow as compared to official announcements about interest rate changes. Financial markets respond slowly to publication of important macroeconomic news if the latter can be predicted on the basis of leading indicators.
\end{abstract}

(c) Publishing house FINANCE and CREDIT, 2017

The editor-in-charge of this article was Irina M. Vechkanova

Authorized translation by Irina M. Vechkanova

\section{Introduction}

High volatility of the currency and stock markets poses a serious problem for central banks and businesses. There are a lot of macroeconomic indicators, such as interest rates, inflation indices, labor market indices, business cycle phase (recession or economic growth), perception indices, which are assessed in the majority of open economies with similar methods. The indicators can be used to detect key factors of the volatility in financial markets internationally.

${ }^{\dagger}$ For the source article, please refer to: Борочкин A.A. Макроэкономические факторы шоков валютного и фондового рынков: метод панельной авторегрессии. Финансы и кредит. 2017. Т. 23. Вып. 15. С. 882-899. URL: https://doi.org/10.24891/fc.23.15.882
Contemporary researches delve into the volatility of financial markets with reference to certain economies or markets of certain assets. For example, E.V. Chirkova, M.S. Sukhanova [1] proved no correlation exists between the Russian companies' announcements and volatility of their stocks in metallurgy and mineral fertilizers. The scholar D.I. Kondratov [2] examines the volatility of the Russian Ruble exchange rate so as to determine how it will be used worldwide as a reserve currency, and overviews approaches to reforming the global currency system [3].

Scholars J.C. Reboredo, M.A. Rivera-Castro [4] focus on the volatility of the global gold market; S. Nazlioglu, U. Soytas, R. Gupta [5] on the volatility 
of the oil market; F. Jawadi, W. Louhichi, H.B. Ameur, A.I. Cheffou [6] on the volatility of the USD exchange rate; I. Turhan, E. Hacihasanoglu, U. Soytas [7] on the volatility of emerging markets.

This article investigates an immediate response of the financial market to macroeconomic announcements, which various open economies assess using the identical methodology. For instance, it would be interesting to observe how the volatility of an exchange rate and a national stock market are influenced by the central bank's announcement on the key interest rate, inflation and labor market. Basic macroeconomic indicators have a long-term effect on the financial market, however, quotations mostly demonstrate slight fluctuation within a short-term run, while considerable changes take place as a response to new information.

\section{Contemporary Studies of the Market Volatility}

Cash flows, international trade volumes, similar cultural background, proximity of time zones, macroeconomic changes may cause the volatility spillovers between financial markets of several countries (D.A. Agudelo, M. Gutiérrez, L. Cardona [8]). During the global financial crisis, starting from Q3 2007 through Q2 2010, basic macroeconomic variables, such as international trade, capitalization of neighboring countries' stock markets had a lower impact on the volatility spillover among countries if compared with announcements on the situation in the largest financial markets of the world (D.E. Allen, M. McAleer, R.J. Powell, A.K. Singh [9]).

High volatility of the national currency exchange rate is usually regarded as a negative factor for any economy (P. Della Corte, T. Ramadorai, L. Sarno [10]). In the mean time, the case of Turkey proves smaller entities can benefit from high volatility of the foreign exchange rate (C. Tunç, M.N. Solakoğlu [11]).

Scholars M. Rambaldi, P. Pennesi, F. Lillo [12] observe how macroeconomic news influence the trade dynamics and the role of surprising announcements on forecasted or expected estimates. J. Barunik, T. Krehlik, L. Vacha emphasize the long-term nature of fluctuations in financial markets [13]. They relied upon high-frequency (intraday) data showing how the foreign exchange rates fluctuate so as to evaluate spiking effects of the volatility. For instance, S. Tian, S. Hamori [14] assess that price shocks are usually cushioned by the market within two to three days. However, the volatility shocks have a gradual and transitional effect on other markets, becoming record high within five to ten days. It is evidence of the long-term memory of volatility time series. W.B. Omrane, C. Hafner [15] observe high-frequency quotations of exchange rates in correlation with basic macroeconomic indicators. The authors registered over a 95-percent cumulative response within six hours after an announcement of any market information.

Although market prices movements can be theoretically explained with basic-indicators models, the Random Walk Hypothesis is also believed to clarify some variance of the exchange rate under certain circumstances. For example, before monetary policy announcement are made, the exchange rate may deviate from fundamentally explained levels due to noisy shocks (C. Redl [16]). Such information shall ignite market behavior studies during news releases that can turn the trend back. The market, more often than not, does not demonstrate any agitation before news releases. The volatility soars just after the announcement. The inverse situation is also possible. During the financial turmoil, high volatility is usually expected in the market. However, some crucial announcements may calm markets down, thus decreasing the volatility. D. Kenourgios, S. Papadamou, D. Dimitriou [17] identified an intraday calming down impact that official announcements about monetary policies had before and after their release.

\section{Data}

Estimates are based on daily quotations of currencies and stock indices in 22 countries $^{1}$ in Europe, Asia, Americas, Africa and Asia Pacific (Table 1). I also use basic economic indicators of the above counties (Table 2) from Q1 2008 through Q4 2016. I checked not only reporting period economic news relates to, but also the exact time of its release. It helps to quantify the response of financial markets to occurrences. I use exchange

\footnotetext{
${ }^{1}$ The Eurozone is regarded as a separate country with the Euro as its currency. Basic economic indicators are applied to the Eurozone, as a whole, rather than to each country of the currency union, in particular.
} 
rates of local currencies against USD as the foreign exchange rates for this study. As for the USA, I apply the Trade Weighted U.S. Dollar Index: Major Currencies. Local stock indices reflect the capitalization of the most marketable listed companies from traditional and highly developed sectors in those countries. For example, S\&P500 (USA), EuroStoxx (Eurozone), FTSE100 (United Kingdom).

The macroeconomic sample includes the following data. Announcements of central banks (dummy variable, 1 - the national central bank made an announcement on the day, 0 - the national central bank did not make any announcement), and their decisions on interest rate adjustments. Official statistical bodies' publications on the inflation and employment, gross domestic product, industrial production, retail trade, etc. Publications of private agencies of economic information and private banks on the market perception indices, business activity indices. Similar techniques are used to obtain this information in line with international agreements. The information is available in most of respective countries (Table 2 provides descriptive statistics of macroeconomic data).

Other macroeconomic indicators of countries are not so easily compared. Housing price dynamics is another important metric. Original techniques are used to assess the indices in each particular country. For example, Nationwide's House Price Index (UK), S\&P Case - Shiller Home Price Indices (USA). However, they are comparable since they are intended to forecast a business cycle phase and inflation in an economy. In the given sample, those indices are available only for five countries.

Purchasing Managers' Index (PMI) also reflects business activities. PMI is measured by private agencies or banks, such as Markit (emerging markets, Eastern Europe), HSBC (emerging markets, $\mathrm{BRICS}^{2}$ ), Caixin (China). The indicator is interesting for market actors since it implies real procurement transactions and, subsequently, allows for reliable forecasts of production orders and demand for products.

\footnotetext{
${ }^{2}$ BRICS countries shall mean Brazil, Russia, India, China and South Africa.
}

Descriptive statistics of logarithmic returns of foreign exchange rates is presented in Table 1. Foreign exchange rates are constructed so that the increased indicator would flag the devaluation of local currencies against the U.S. dollar. If the U.S. dollar index grows, it means the devaluation of the U.S. dollar against major currencies. As seen in Table 1, China and Japan are cases when national currencies and their exchange rates are somewhat pegged to the U.S. dollar. They have the smallest standard skewness of returns but very high kurtosis coefficient due to one-time intentional devaluations against the U.S. dollar. The high kurtosis coefficient of Brazil, South Korea, Russia qualifies them as emerging economies, where drastic changes in foreign exchange rates are possible.

Risk metrics, such as Value-at-Risk and average expected loss, in particular, indicate that currencies in such countries as Brazil, Bulgaria, Poland, Russia and South Africa are exposed to significant and extraordinary devaluation (Table 1).

The Ljung-Box test proves the majority of currency pairs correlates, including the Ruble-based currency pairs, thus justifying the use of autoregression models. The Jarque-Bera test is significant at one-percent level, thus warning about an abnormal distribution of returns of all currency pairs. The unit roots tests (the augmented Dickey-Fuller test and Philips-Perron test) prove $(p<0.05)$ stationarity of the time series in question (Table 1), thus making them applicable to the regression analysis. Returns of stock indices were subject to the similar tests, with the same conclusions being made.

Descriptive statistics of macroeconomic data are given in Table 2. For panel analysis purposes, time series of indicators shall be available for the majority of panels (countries). If data on a certain country are missing, the country is excluded out of the observation. As seen in the Table, data on key interest rates, inflation, employment, business activity are available in relation to most countries. Standard deviation of indicators is much less than their averages, thus indicating the reliability and applicability of data in verifying statistical hypotheses.

The available macroeconomic data were processed in the following way. Inflation metrics are published 
as monthly percentage points of movements in prices for consumer goods, production goods or real estate and can be construed as negative return on cash held. Although being negative in certain cases, the official interest rate is a benchmark of the return on risk-free assets. Hence, to compare the return and gain from foreign exchange or stock indices, inflation metrics and official interest rates were used as they are. Official announcements of central banks represent dummy variables, which shall not be transformed either. The remaining indicators are published as absolute values. I calculated their logarithmic return and included transformed data into the sample.

In addition to the formal verification of data, descriptive statistics analysis in Table 2 reveals interesting facts. First, Sweden, China and South Korea demonstrate deflation of their costs (averages of the Producer Price Index are negative). As for Sweden, this may stem from its access to cheap oil in comparison with the rest of Europe. China and South Korea are presumed to increase their labor productivity or tend to cheap workforce from agriculture (Table 2). Second, there is inconsistency between intuitive perceptions and data on expected volatility of the market when economic news is released. The data is given in the bottom line of the right-hand column of the table per each economic indicator and national average. Considering the large scale of the U.S. economy and broad trading ties with other countries, U.S. data are expected to cause the highest volatility of the global financial market in comparison with other countries. However, the USA is a leader in terms of the average expected volatility caused by announcements. The reason is that numerous important news concerns the U.S. economy, thus averaging out (reducing) the market volatility in the long run (Table 2). If I focus on types of macroeconomic news, rather than countries, the average expected volatility of the market reaches its highest point at the moment of announcements. It is consistent with generally accepted views. Political events can cause dramatic changes in the market situation. They are more difficult to predict than economic developments (Table 2).

\section{Methodology}

Two general approaches are mainly used to observe the volatility of foreign exchange rates. The first one involves various types of models with conditional heteroskedasticity (GARCH). Such models are applied to evaluate and assess each country's indicators in particular. As per the second approach, assessments are made for all the sampled countries. It requires panel autoregression models.

Analyzing panel data, I may use hidden variables to consider and exclude individual distinctions of observable items. In the mean time, vector autoregressive models help examine several time series of economic variable and their correlation. For example, foreign exchange rate, stock index, inflation, etc. in a certain country. Therefore, if this research aims to find general economic patterns showing the reasons why the volatility of financial markets in different countries increases, the panel vector autoregressive model is a proper option. In previous researches, the panel vector autoregressive model was used to examine the mutual correlation of the foreign exchange rate in 29 countries (A. Grossmann, I. Love, A.G. Orlov [18]), European countries (M.A. Dąbrowski, M. Papież, S. Śmiech [19]), and Sub-Saharan countries of Africa (I.O. Oseni [20]). In Russia, panel models are applied by S.M. Guriev, A.D. Kolotilin, K.I. Sonin [21] to study the oil market volatility. E.A. Fedorova, A.E. Nikolaev, E.S. Mazalov ${ }^{3}$ resort to econometric methods to evaluate spillover effects (mutual influence) in Russia's defense industry.

The general expression of the panel vector autoregressive model can be presented like it is put in the research by A. Grossmann, I. Love, A. G. Orlov [19]:

$$
Z_{i t}=\Gamma_{0}+\Gamma_{1} Z_{i t-1}+f_{i}+\varepsilon_{i t} \text {, }
$$

where $Z_{i t}$ is the vector of key variables;

$f_{i}$ denotes fixed effects that reflect all concealed and time independent characteristics of a certain country (area, the number of population, international trade agreements, exchange rate regimes, etc.);

\footnotetext{
${ }^{3}$ Fedorova E.A., Nikolaev A.E., Mazalov E.S. [Spillover effects in the defense industry]. Finansy $i$ Kredit = Finance and Credit, 2016, no. 1, pp. 2-11. (In Russ.)
} 
$i$ and $t$ are indices signifying the country and time interval respectively.

The time lag of the model is chosen by minimizing the Akaike information criterion ${ }^{4}$ or Bayesian information criterion, which are determined for several models with identical sets of input variables and the different number of lags only. In most cases, it is enough to check lags, from one to four. Lag-one models, i.e. models based on previous-period data, happen to be the best option.

Based on equation (1), I review three models, which help assess an impact of macroeconomic shocks on the exchange rate of the local currency and stock index: the monetary policy modification model (2), the economic and business environment modification model (3) and the comprehensive model (4).

The monetary policy modification model (2) includes such variables as the exchange rate Exch $R_{i t}$, stock index Stocklit, key rate Key $R_{i t}$ central bank's announcements $C B_{i t}$, Consumer Price Index $C P l_{i t}$, Producer Price Index $P P l_{i t}$. The model traces the link between the financial market and monetary factors (cycles of interest rate increases and decreases as a response to the inflation).

$$
\begin{gathered}
Z_{i t}=\left(\operatorname{ExchR}_{i t}, \operatorname{StockI}_{i t}, \operatorname{KeyR}_{i t}, C B_{i t}, C P I_{i t},\right. \\
\left.P P I_{i t}\right) .
\end{gathered}
$$

The economic and business environment modification model (3) includes the exchange rate $E x c h R_{i t,}$ stock index Stock $l_{i t}$, key rate Key $R_{i t}$ Industrial Production Index Prod $_{i t}$ Purchasing Managers' Index $P M I_{\text {it. }}$. The model detects the correlation between the financial market and a business cycle (recession or growth).

$$
Z_{i t}=\left(\operatorname{ExchR}_{i t}, \operatorname{StockI}_{i t}, \operatorname{KeyR}_{i t}, \operatorname{Prod}_{i t}, P M I_{i t}\right) \text {. }
$$

The comprehensive model (4) includes the exchange rate $E x c h R_{i t}$, stock index Stocklit, key rate Key $R_{i t}$, Industrial Production Index Prod $_{i t}$ unemployment rate $J_{i t}$.

$$
Z_{i t}=\left(\operatorname{ExchR}_{i t}, \operatorname{StockI}_{i t}, \operatorname{KeyR}_{i t}, \operatorname{Prod}_{i t}, J_{i t}\right) .
$$

\footnotetext{
${ }^{4}$ The Akaike information criterion shows how many errors the model with limited variables has in comparison with the complete or ideal model that includes all factors. The Akaike information criterion of the ideal model is zero, by its nature.
}

In this model, industrial production trends signify a business cycle phase, while the unemployment rate generalizes the outcome of the central bank's monetary policy for stimulating or hindering the business activity and inflation.

\section{Results}

The main results of panel vector autoregression are presented in Table 3. I use a one-period lag for all the three models. I choose this lag by comparing the quality of the models with different lags in line with the Akaike information criterion.

Please note that Table 3 is divided into two sections Exchange Rate and Stock Index. The sections contain regression model coefficients in relation to factors that influence the two resultant indicators. The variables are deemed to correlate, if the regression coefficient is statistically meaningful (such coefficients are marked with an asterisk in the table). As seen in the table, the exchange rate demonstrates the strongest response to news informing that central banks altered interest rates $(-0.00511, p<0.05)$ and the stock market fluctuates $(-0.0126, p<0.05)$. News about the inflation and real economy indices (industrial production, PMI) does not invoke an immediate response of the currency market.

The stock market and the national currency market are closely related. Fluctuations in the one echo through the other immediately. The transmission of volatility from the currency market to the stock one and the autocorrelation of the stock market have special statistical significance: $0.075, p<0.001$ and $-0.0434, p<0.001$, respectively.

News about the industrial production induces a statistically significant response of the stock market $(0.0014, p<0.01)$. The three models are based on 11 to 13 panels (countries) with more than 15 thousand observation being made in total. The sample is representative.

Impulse response functions give an illustrative view of the statistical significance of the regression coefficients. They are presented in Table 1 for the monetary policy modification model and Table 2 for the comprehensive model. 
As displayed in the Figures, the market completely overwhelms a news shock in a four-day time, with record high indicators being registered on the following day. The Figures also indicate the bounds of a 95-percent confidence interval for impulse response functions, which help assess the statistical significance of regression coefficients. Given the dependence exists, the response function graph and confidence bounds are above or below zero in case of a positive or negative correlation, respectively. Sections Key Rate and Exchange rate, and Exchange Rate and Stock are noteworthy.

As per the first graph, if the local central bank raises an interest rate, the national currency immediately strengthens (in the graph, exchange rates are constructed so that a drop would mean a growth of the national currency against USD). As per the second graph, the local currency devaluation entails an immediate growth in the stock index denominated in the national currency. The correlation is rather evident, for the money devaluation does not necessarily mean a drop in the company value. As the section CPI and Stock Index shows, announcements on a growth in CPI leads to an immediate upward revaluation of stock assets. From economic perspectives, the correlation is quite justifiable, however, the statistical significance was not corroborated with the formal test, with its results reported in Table 3.

Fig. 2 depicts impulse response functions for the comprehensive model including monetary and economic factors. The sections Industrial Production and Stock Index display that positive announcements on industrial production makes the stock market grow on the following day.

The economic theory provides the convincing rationale for the correlation between inflation and employment metrics with the currency and stock markets. Nevertheless, I do identify the statistically significant correlation between such announcements and an immediate response of the financial market. It stems from monetary policies of contemporary central banks, especially, in the USA and Europe. The increased inflation is not considered as a prerequisite for the central bank to raise interest rates. Moreover, if the inflation rises once, it will not necessarily gain momentum in the future. Hence, financial markets do not tend to actively respond to tentative data, awaiting official announcements of monetary authorities on changes in interest rates. As for employment metrics, the financial market seems to consider leading indicators, i.e. the Industrial Production Index, and foresees the changes. Thus, the market volatility will be moderate as labor market statistics are published.

Other sections in Fig. 1 and 2 are given for reference. They are difficult to interpret from economic perspectives for purposes of this research. For example, it is not that easy to substantiate the psychological correlation between the publication of the Producer Price Index and Consumer Price Index.

I construct regressions in relation to other macroeconomic variables. Announcements on confidence of businesses and consumers, leading indicators (retail trade, Purchasing Managers' Index) do not have an immediate impact on the volatility of the currency and stock market. The reason is that local markets mostly react to the publication of such indicators in relation to the U.S. economy. While similar information on the other country's market is released, prices have already been adjusted for the information. The panel model is designated to reveal significant coefficients only if a certain phenomenon is typical of most panels, rather than one or two. In this research, I do not weight macroeconomic indicators by size of respective economies. Thus, each country has the same weight in the models.

Announcements on gross domestic product do not invoke the market volatility since the indicator, I presume, is published within a considerable time interval after the reporting period, thus allowing the market to embed this information in prices.

\section{Conclusions}

The research results in the following conclusions. The currency and stock markets are mutually related. If one of them experiences any changes, the other one reacts immediately. Considering macroeconomic factors that cause the volatility of the stock market, I should point out changes in the interest rate, and Consumer Price Index. In case of the stock market, these factors are announcements 
on the interest rate and industrial production. The market can forecast the employment situation through leading indicators. Thus, the respective response to those announcements is mild. Announcements on the inflation also have a small impact on the market volatility since market actors prefer to know official authorities' decision on monetary policies and respective changes.

The findings can be applied by regulatory authorities to outline monetary and economic policies of the State. Private investors should consider the market volatility on the days of relevant announcements, with their statistical significance for the currency and stock market being proved in this research.

Further studies might focus on the intraday volatility of the financial market upon the release of macroeconomic announcements.

\section{Table 1}

Descriptive statistics of exchange rate returns. Data for 01 2008-04 2016

\begin{tabular}{|c|c|c|c|c|c|c|c|c|c|c|}
\hline \multirow{2}{*}{$\begin{array}{l}\text { Country } \\
\text { (a group of countries) }\end{array}$} & \multicolumn{4}{|c|}{ Moments } & \multicolumn{2}{|l|}{ Risk } & \multirow{2}{*}{$\mathrm{JB}^{7}$} & \multirow{2}{*}{$\mathrm{BL}^{8}$} & \multicolumn{2}{|c|}{ Unit roots $^{9}$} \\
\hline & Mean $^{1}$ & $s d^{2}, \%$ & $\mathbf{s k}^{3}$ & $\mathbf{k r t}^{4}$ & $\operatorname{VaR}^{5}, \%$ & $E S^{6}, \%$ & & & $\mathrm{ADF}^{10}$ & $\mathrm{PP}^{11}$ \\
\hline Australia & 0 & 0.89 & 0.89 & 16.14 & -1.28 & -1.96 & 0 & $7.62^{* *}$ & $-37.51^{*}$ & $-2,803.31^{*}$ \\
\hline Eurozone & 0 & 0.61 & 0.21 & 7.68 & -0.91 & -1.35 & 0 & 0.01 & $-37.42^{*}$ & $-2,776.24^{*}$ \\
\hline Brazil & 0 & 0.95 & 1.59 & 29.05 & -1.39 & -2.08 & 0 & 0.04 & $-27.87^{*}$ & $-1,443.46^{*}$ \\
\hline Canada & 0 & 0.63 & -0.13 & 8.63 & -1 & -1.48 & 0 & 0.3 & $-38.03^{*}$ & $-2,730.27^{*}$ \\
\hline China & 0 & 0.12 & 1.33 & 33.47 & -0.17 & -0.28 & 0 & 0.85 & $-36.47^{*}$ & $-2,802.64^{*}$ \\
\hline Czech Republic & 0 & 0.79 & -0.02 & 7.99 & -1.23 & -1.81 & 0 & 0.21 & $-37.04^{*}$ & $-2,747.52^{*}$ \\
\hline Denmark & 0 & 0.61 & -0.17 & 7.12 & -0.98 & -1.42 & 0 & 0.68 & $-37.13^{*}$ & $-2,726.8^{*}$ \\
\hline United Kingdom & 0 & 0.62 & 0.89 & 18.83 & -0.91 & -1.34 & 0 & 2.92 & $-36.14^{*}$ & $-2,583.26^{*}$ \\
\hline Bulgaria & 0 & 0.97 & 0.05 & 6.59 & -1.52 & -2.22 & 0 & 0.67 & $-37.25^{*}$ & $-2,675.51^{*}$ \\
\hline India & 0 & 0.67 & -0.45 & 12.51 & -1.02 & -1.57 & 0 & 0.24 & $-38.51^{*}$ & $-2,744.24^{*}$ \\
\hline Japan & 0 & 0.65 & -0.29 & 8.23 & -1.03 & -1.54 & 0 & 0.54 & $-38.55^{*}$ & $-2,701.69^{*}$ \\
\hline South Korea & 0 & 0.77 & -0.01 & 36.82 & -0.93 & -1.74 & 0 & 0.93 & $-37.75^{*}$ & $-2,459.54^{*}$ \\
\hline New Zealand & 0 & 0.89 & 0.34 & 9.16 & -1.35 & -1.99 & 0 & 0.67 & $-37.16^{*}$ & $-2,657.41^{*}$ \\
\hline Norway & 0 & 0.82 & -0.01 & 8.02 & -1.29 & -1.84 & 0 & 1.27 & $-39.31^{*}$ & $-2,655.94^{*}$ \\
\hline Poland & 0 & 0.94 & 0.12 & 7.72 & -1.4 & -2.14 & 0 & 0.74 & $-37.08^{*}$ & $-2,604.11^{*}$ \\
\hline Russia & 0 & 0.95 & 0.06 & 49.03 & -1.19 & -2.11 & 0 & 1.21 & $-36.81^{*}$ & $-2,498.09^{*}$ \\
\hline Singapore & 0 & 0.36 & -0.04 & 8.19 & -0.55 & -0.85 & 0 & $6.83^{* *}$ & $-39.04^{*}$ & $-2,844.48^{*}$ \\
\hline South Africa & 0 & 1.04 & 0.45 & 9.17 & -1.5 & -2.21 & 0 & 1.52 & $-37.32^{*}$ & $-2,563.47^{*}$ \\
\hline Sweden & 0 & 0.8 & -0.22 & 7.17 & -1.25 & -1.84 & 0 & 2.85 & $-39.33^{*}$ & $-2,712.88^{*}$ \\
\hline Switzerland & 0 & 0.7 & -1.29 & 40.86 & -1.07 & -1.62 & 0 & $22.33^{* * *}$ & $-37.06^{*}$ & $-2,539.54^{*}$ \\
\hline Turkey & 0 & 0.78 & 0.38 & 11.13 & -1.11 & -1.62 & 0 & $8.16^{* *}$ & $-36.27^{*}$ & $-2,552.06^{*}$ \\
\hline USA & 0 & 0.46 & -0.45 & 8.49 & -0.74 & -1.09 & 0 & 0.34 & $-38.04^{*}$ & $-2,813.01^{*}$ \\
\hline
\end{tabular}

${ }^{1}$ Mean is the mean value.

${ }^{2}$ sd is standard deviation.

${ }^{3} \mathrm{sk}$ is the kurtosis coefficient.

${ }^{4} \mathrm{krt}$ is the asymmetry coefficient.

${ }^{5} \mathrm{VaR}$ is Value-at-Risk.

${ }^{6} \mathrm{ES}$ is the average expected losses.

${ }^{7} \mathrm{JB}$ is $p$-value of the Jarque-Bera test for normality.

${ }^{8} \mathrm{BL}$ is the Ljung-Box test for autocorrelation.

${ }^{9}$ Unit roots test (stationarity test).

${ }^{10} \mathrm{ADF}$ is the augmented Dickey-Fuller test.

${ }^{11} \mathrm{PP}$ is the Phillips-Perron test.

${ }^{*} p<0.05$. 
${ }^{* *} p<0.01$.

${ }^{* * *} p<0,001$.

Source:Authoring, based on currency quotes retrieved from Investing.com financial portal. URL: https://www.investing.com; Trade Weighted U.S. Dollar Index: Major Currencies [DTWEXM] retrieved from FRED, Federal Reserve Bank of St. Louis. URL: https://fred.stlouisfed.org/series/DTWEXM

\section{Table 2}

Monetary, economic and business determinants of currency exchange movements. Descriptive statistics. Data for 01 2008-04 2016

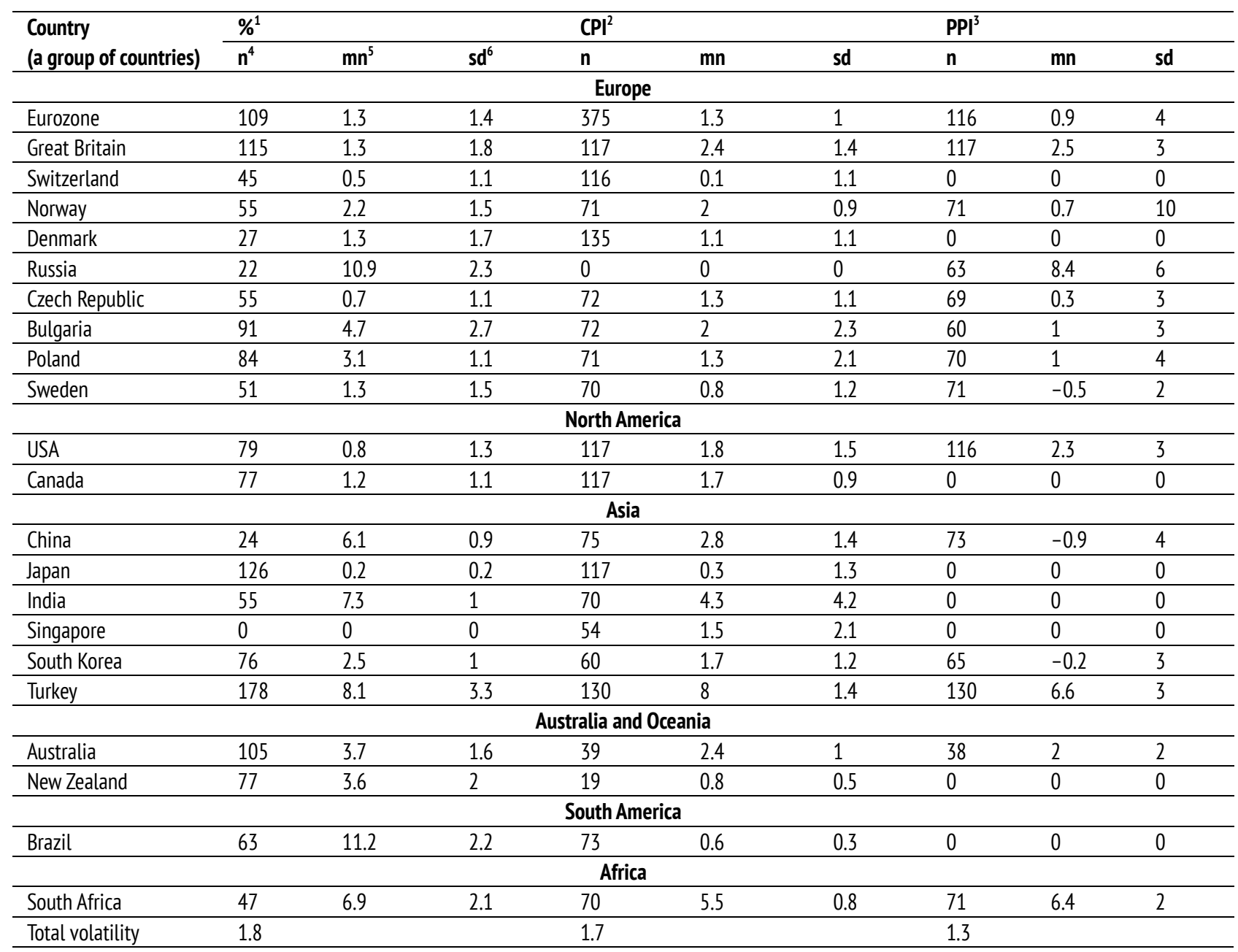

${ }^{1} \%$ is the interest rate set by the central bank.

${ }^{2} \mathrm{CPI}$ is the Consumer Price Index.

${ }^{3} \mathrm{PPI}$ is the Producer Price Index.

${ }^{4} \mathrm{n}$ is the number of observations.

${ }^{5} \mathrm{mn}$ is the mean.

${ }^{6} \mathrm{sd}$ is standard deviation.

\section{Continued from the above table}

\begin{tabular}{|c|c|c|c|c|c|c|c|c|}
\hline \multirow{2}{*}{$\begin{array}{l}\text { Country (a group of } \\
\text { countries) }\end{array}$} & \multicolumn{3}{|l|}{$\mathrm{J}^{1}$} & \multicolumn{3}{|c|}{$\mathrm{PMI}^{2}$} & \multirow{2}{*}{$\mathrm{CB}^{3}$} & \multirow{2}{*}{ V.ty ${ }^{4}$} \\
\hline & $\mathrm{n}$ & $\mathrm{mn}$ & sd & $\mathrm{n}$ & $\mathrm{mn}$ & sd & & \\
\hline \multicolumn{9}{|c|}{ Europe } \\
\hline Eurozone & 117 & 10.1 & 1.6 & 229 & 50.1 & 5.1 & 1,225 & 2.1 \\
\hline Great Britain & 110 & 6.8 & 1.2 & 118 & 51.7 & 5.1 & 962 & 2.2 \\
\hline Switzerland & 0 & 0 & 0 & 113 & 52.5 & 7.2 & 187 & 1.8 \\
\hline
\end{tabular}




\begin{tabular}{|c|c|c|c|c|c|c|c|c|}
\hline Norway & 71 & 89.1 & 6.5 & 0 & 0 & 0 & 0 & 1 \\
\hline Denmark & 68 & 4.2 & 0.4 & 0 & 0 & 0 & 0 & 1 \\
\hline Russia & 66 & 5.6 & 0.6 & 67 & 50.4 & 1.8 & 0 & 1 \\
\hline Czech Republic & 71 & 7.5 & 1.2 & 66 & 53.4 & 3.4 & 0 & 1 \\
\hline Bulgaria & 68 & 8.9 & 2.1 & 71 & 52.7 & 2.7 & 0 & 1 \\
\hline Poland & 0 & 0 & 0 & 59 & 51.4 & 2.4 & 0 & 1.1 \\
\hline Sweden & 69 & 7.6 & 0.7 & 0 & 0 & 0 & 0 & 1 \\
\hline \multicolumn{9}{|c|}{ North America } \\
\hline USA & 117 & 7.1 & 1.8 & 109 & 53.6 & 1.9 & 2,462 & 1.7 \\
\hline Canada & 114 & 7.1 & 0.7 & 65 & 55.4 & 5.4 & 344 & 2.2 \\
\hline \multicolumn{9}{|c|}{ Asia } \\
\hline China & 0 & 0 & 0 & 215 & 50.4 & 1.9 & 0 & 1.8 \\
\hline Japan & 116 & 4.1 & 0.7 & 139 & 49.9 & 4.2 & 748 & 1.9 \\
\hline India & 0 & 0 & 0 & 0 & 0 & 0 & 0 & 1 \\
\hline Singapore & 33 & 2 & 0.1 & 52 & 50.1 & 0.9 & 0 & 1 \\
\hline South Korea & 63 & 3.4 & 0.3 & 62 & 49.5 & 1.4 & 0 & 1 \\
\hline Turkey & 0 & 0 & 0 & 0 & 0 & 0 & 0 & 0.9 \\
\hline \multicolumn{9}{|c|}{ Australia and Oceania } \\
\hline Australia & 116 & 5.3 & 0.6 & 86 & 48.7 & 4.1 & 842 & 2.1 \\
\hline New Zealand & 38 & 5.7 & 1.1 & 95 & 53.6 & 3.3 & 260 & 1.9 \\
\hline \multicolumn{9}{|c|}{ South America } \\
\hline Brazil & 66 & 6.4 & 1.9 & 53 & 48.3 & 2.7 & 0 & 1 \\
\hline \multicolumn{9}{|c|}{ Africa } \\
\hline South Africa & 21 & 25.2 & 0.8 & 55 & 51 & 2.9 & 0 & 1 \\
\hline Total volatility & 1.7 & & & 1.5 & & & 2 & - \\
\hline
\end{tabular}

${ }^{1} \mathrm{~J}$ is the unemployment rate.

${ }^{2} \mathrm{PMI}$ is Purchasing Managers' Index.

${ }^{3} \mathrm{CB}$ is the central bank's announcements on monetary policies.

${ }^{4} \mathrm{~V}$.ty is the average expected volatility.

Source:Authoring. Economic metrics and volatility data retrieved from FXStreet. URL: https://www.fxstreet.com/economic-calendar

Table 3

Exchange rate volatility assessment under Panel VAR method

\begin{tabular}{|c|c|c|c|}
\hline Indicator & Monetary Policy (1) & $\begin{array}{l}\text { Economic and Business } \\
\text { Environment (2) }\end{array}$ & Comprehensive Model (3) \\
\hline \multicolumn{4}{|c|}{ Exchange Rate } \\
\hline Exchange rate & $-0.00363(-0.32)^{1}$ & $-0.00437(-0.29)$ & $-0.0217(-1.45)$ \\
\hline Stock index & $0.00906(1.86)$ & $-0.00501(-0.91)$ & $-0.0126^{*}(-2.02)$ \\
\hline Key rate & $-0.00511^{*}(-2.42)$ & $-0.00432(-1.05)$ & $-0.00868^{*}(-2.13)$ \\
\hline Central Bank's announcements & $0.0000738(0.38)$ & - & - \\
\hline Consumer Price Index & $0.000112(0.16)$ & - & - \\
\hline Producer Price Index & $0.000375(0.80)$ & - & - \\
\hline Industrial production & - & $0.000305(0.73)$ & $0,0000954(0,27)$ \\
\hline Purchasing Managers' Index & - & $-0.00717(-1.00)$ & - \\
\hline Unemployment rate & - & - & $-0.00858(-1,09)$ \\
\hline \multicolumn{4}{|c|}{ Stock Index } \\
\hline Exchange rate & $-0.075^{* * *}(-4.34)$ & $0.0356(1.72)$ & $0.0375(1.82)$ \\
\hline Stock index & $-0.0434^{* * *}(-3.93)$ & $-0.0199(-1.68)$ & $-0.0388^{* *}(-3.2)$ \\
\hline Key rate & $0.00229(0.76)$ & $0.00456(0.86)$ & $0.00502(1.06)$ \\
\hline Central Bank's announcements & $-0.00046(-1.22)$ & - & - \\
\hline Consumer Price Index & $0.0027(1.83)$ & - & - \\
\hline Producer Price Index & $0.00115(1.36)$ & - & - \\
\hline
\end{tabular}

Please cite this article as: Borochkin A.A. Macroeconomic Determinants of the Currency and Stock Market Shocks: A Panel VAR Approach. 


\begin{tabular}{llll}
\hline Industrial production & - & $0.0014^{* *}(2.71)$ & $0.00134^{* *}(2.71)$ \\
\hline Purchasing Managers' Index & - & $-0.00168(-0.12)$ & - \\
\hline Unemployment rate & - & - & $0,000777(0,07)$ \\
\hline Total observations & 18,812 & 16,444 & 15,253 \\
\hline The number of data panels (countries) & 13 & 12 & 11 \\
\hline Chi-square Statistic & $168.9(108)$ & $126.8(75)$ & $126.1(75)$ \\
\hline
\end{tabular}

${ }^{1} t$-statistics in brackets.

${ }^{*} p<0,05,{ }^{* *} p<0,01,{ }^{* * *} p<0,001$.

Source:Authoring

\section{Figure 1}

Impulse response function for the model with monetary metrics

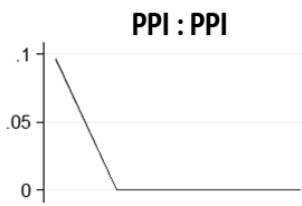

CPI : PPI

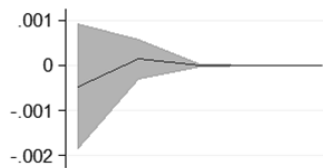

Key Rate : PPI

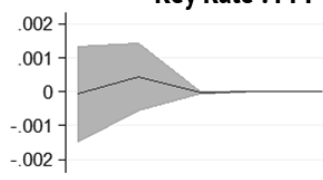

Exchange Rate : PPI

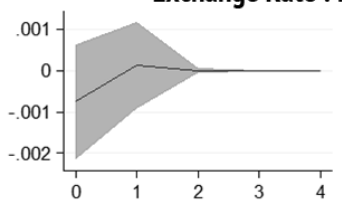

PPI : CPI

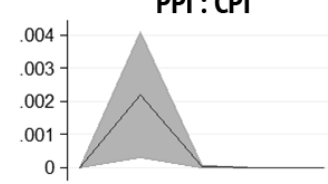

CPI : CPI

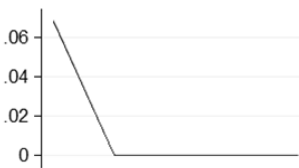

Key Rate : CPI

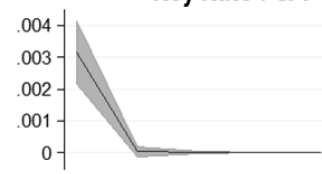

Exchange Rate : CPI

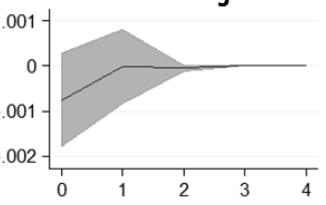

PPI : Stock Index

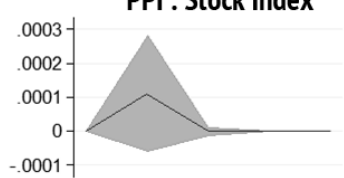

CPI : Stock Index

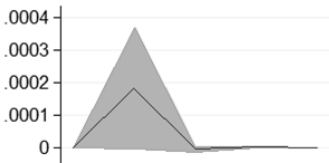

Key Rate : Stock Index

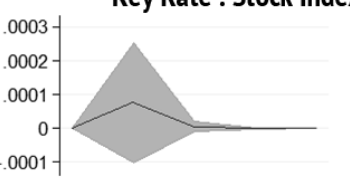

Exchange Rate : Stock Index

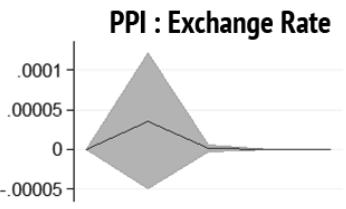

CPI : Exchange Rate

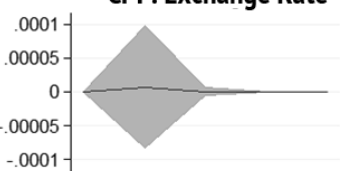

Key Rate : Exchange Rate

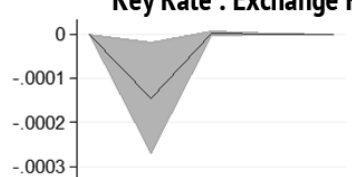

\section{The number of days}

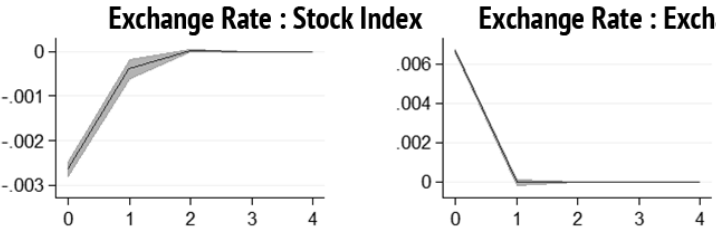

95\% confidence interval

— Impulse Response Function

* Exchange Rate is the exchange rate of the local currency against the U.S. dollar or the U.S. dollar index, Stock Index is the stock market index, Key Rate is the key rate set by the central bank, CPI is the Consumer Price Index, PPI is the Producer Price Index.

Source:Authoring 


\section{Figure 2}

Impulse response function for the model with monetary and economic metrics
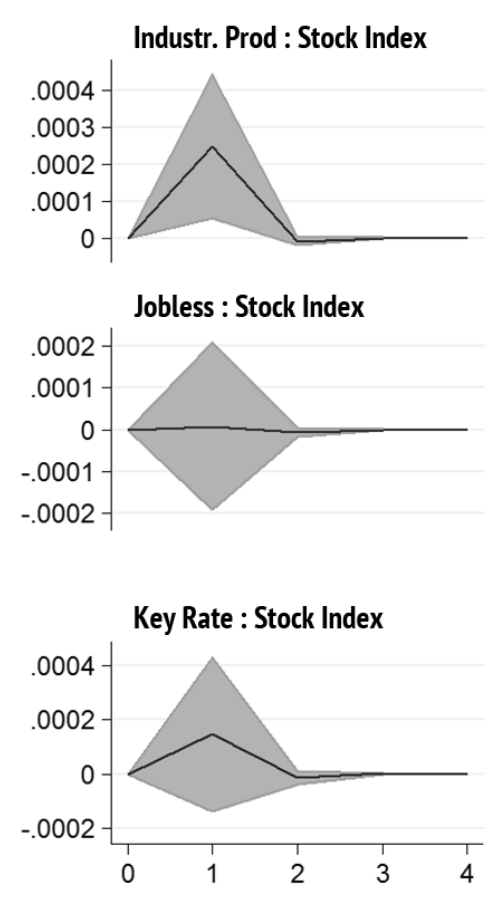
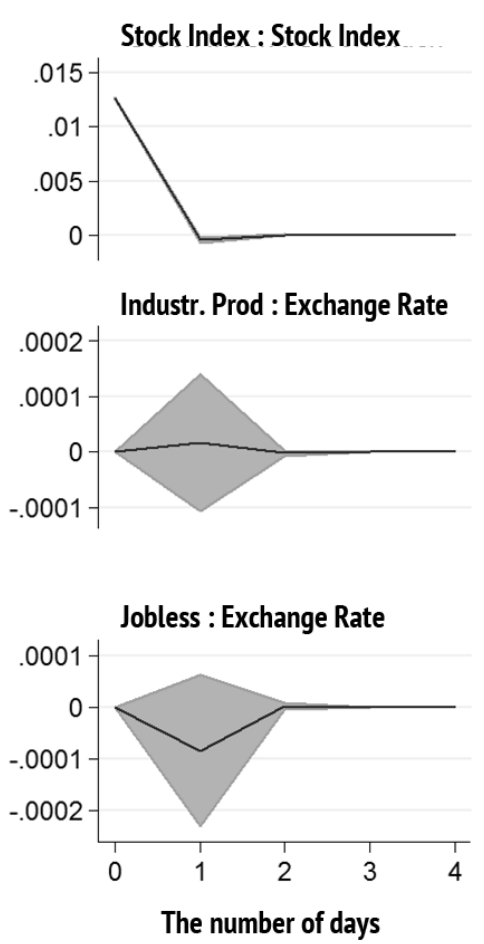
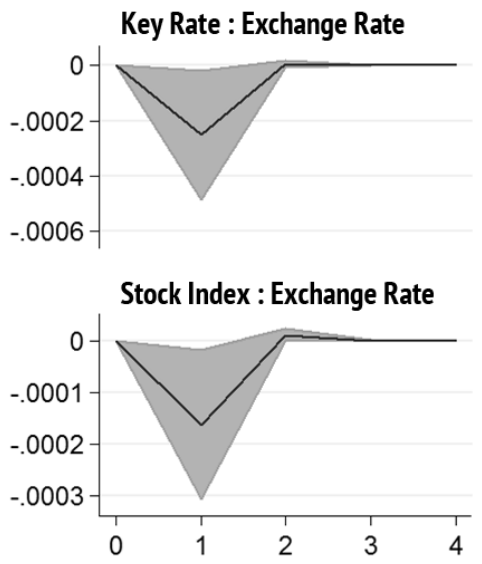

$$
\text { 95\% confidence interval } \quad \text { - Impulse Response Function }
$$

* Exchange Rate is the exchange rate of the local currency against the U.S. dollar or the U.S. dollar index, Stock Index is the stock market index, Key Rate is the key rate set by the central bank, Industr. Prod is industrial production, Jobless is the unemployment rate.

Source:Authoring

\section{References}

1. Chirkova E.V., Sukhanova M.S. [Impact of the earnings' guidance provided by public companies on their market capitalization and share price volatility in the Russian stock market]. Korporativnye finansy = Journal of Corporate Finance Research, 2013, no. 4, pp. 37-52. (In Russ.)

2. Kondratov D.I. [Formation of the Russian rubles as an international currency]. Ekonomicheskii zhurnal VShE = The HSE Economic Journal, 2012, vol. 16, no. 3, pp. 367-403. (In Russ.)

3. Kondratov D.I. [Recent approaches to reforming the global monetary system]. Ekonomicheskii zhurnal VShE $=$ The HSE Economic Journal, 2015, vol. 19, no. 1, pp. 128-157. (In Russ.)

4. Reboredo J.C., Rivera-Castro M.A. Gold and Exchange Rates: Downside Risk and Hedging at Different Investment Horizons. International Review of Economics \& Finance, 2014, vol. 34, pp. 267-279. URL: https://doi.org/10.1016/j.iref.2014.07.005

5. Nazlioglu S., Soytas U., Gupta R. Oil Prices and Financial Stress: A Volatility Spillover Analysis. Energy Policy, 2015, vol. 82, pp. 278-288. URL: https://doi.org/10.1016/j.enpol.2015.01.003 
6. Jawadi F., Louhichi W., Ameur H.B., Cheffou A.I. On Oil-US Exchange Rate Volatility Relationships: An Intraday Analysis. Economic Modelling, 2016, vol. 59, pp. 329-334.

URL: https://doi.org/10.1016/j.econmod.2016.07.014

7. Turhan I., Hacihasanoglu E., Soytas U. Oil Prices and Emerging Market Exchange Rates. Emerging Markets Finance and Trade, 2013, vol. 49, iss. S1, pp. 21-36.

8. Agudelo D.A., Gutiérrez M., Cardona L. Volatility Transmission between US and Latin American Stock Markets: Testing the Decoupling Hypothesis. Research in International Business and Finance, 2017, vol. 39, part A, pp. 115-127. URL: https://doi.org/10.1016/j.ribaf.2016.07.008

9. Allen D.E., McAleer M., Powell R.J., Singh A.K. Volatility Spillovers from Australia's Major Trading Partners Across the GFC. International Review of Economics \& Finance, 2017, vol. 47, pp. 159-175.

URL: https://doi.org/10.1016/j.iref.2016.10.007

10. Della Corte P., Ramadorai T., Sarno L. Volatility Risk Premia and Exchange Rate Predictability. Journal of Financial Economics, 2016, vol. 120, iss. 1, pp. 21-40. URL: https://doi.org/10.1016/j.fineco.2016.02.015

11. Tunç C., Solakoğlu M.N. Does Exchange Rate Volatility Matter for International Sales? Evidence from US Firm Level Data. Economics Letters, 2016, vol. 149, pp. 152-156.

URL: https://doi.org/10.1016/j.econlet.2016.08.008

12. Rambaldi M., Pennesi P., Lillo F. Modeling Foreign Exchange Market Activity around Macroeconomic News: Hawkes-Process Approach. Physical Review, 2015, vol. 91, iss. 1.

13. Barunik J., Krehlik T., Vacha L. Modeling and Forecasting Exchange Rate Volatility in Time-Frequency Domain. European Journal of Operational Research, 2016, vol. 251, iss. 1, pp. 329-340.

URL: https://doi.org/10.1016/j.ejor.2015.12.010

14. Tian S., Hamori S. Time-Varying Price Shock Transmission and Volatility Spillover in Foreign Exchange, Bond, Equity, and Commodity Markets: Evidence from the United States. The North American Journal of Economics and Finance, 2016, vol. 38, iss. C, pp. 163-171. URL: https://doi.org/10.1016/j.najef.2016.09.004

15. Omrane W.B., Hafner C. Macroeconomic News Surprises and Volatility Spillover in Foreign Exchange Markets. Empirical Economics, 2015, vol. 48, iss. 2, pp. 577-607.

16. Redl C. Noisy News and Exchange Rates: A SVAR Approach. Journal of International Money and Finance, 2015, vol. 58, pp. 150-171. URL: https://doi.org/10.1016/j.jimonfin.2015.08.002

17. Kenourgios D., Papadamou S., Dimitriou D. Intraday Exchange Rate Volatility Transmissions across QE Announcements. Finance Research Letters, 2015, vol. 14, pp. 128-134.

URL: https://doi.org/10.1016/j.frl.2015.05.007

18. Grossmann A., Love I., Orlov A.G. The Dynamics of Exchange Rate Volatility: A Panel VAR Approach. Journal of International Financial Markets, Institutions and Money, 2014, vol. 33, pp. 1-27. URL: https://doi.org/10.1016/j.intfin.2014.07.008

19. Dąbrowski M.A., Papież M., Śmiech S. Exchange Rates and Monetary Fundamentals in CEE Countries: Evidence from a Panel Approach. Journal of Macroeconomics, 2014, vol. 41, pp. 148-159. URL: https://doi.org/10.1016/j.jmacro.2014.05.005 
20. Oseni I.O. Exchange Rate Volatility and Private Consumption in Sub-Saharan African Countries: A System-GMM Dynamic Panel Analysis. Future Business Journal, 2016, vol. 2, iss. 2, pp. 103-115. URL: https://doi.org/10.1016/j.fbj.2016.05.004

21. Guriev S.M., Kolotilin A.D., Sonin K.I. [Determinants of expropriationing the oil sector: A theory and evidence from panel data]. Ekonomicheskii zhurnal VShE = The HSE Economic Journal, 2008, vol. 12, no. 2, pp. 151-175. (In Russ.)

\section{Conflict-of-interest notification}

I, the author of this article, bindingly and explicitly declare of the partial and total lack of actual or potential conflict of interest with any other third party whatsoever, which may arise as a result of the publication of this article. This statement relates to the study, data collection and interpretation, writing and preparation of the article, and the decision to submit the manuscript for publication. 